\title{
Genetic distance estimated by RAPD markers and its relationship with hybrid performance in maize
}

\author{
Daniela Cristina Bruel(1), Valéria Carpentieri-Pípolo(1) ${ }^{(1)}$ tonio Carlos Gerage ${ }^{(2)}$, Nelson da Silva Fonseca Júnior ${ }^{(2)}$, \\ Cássio Egídio Cavenaghi Prete ${ }^{(1)}$, Claudete de Fátima Ruas ${ }^{(3)}$, Paulo Maurício Ruas ${ }^{(3)}$, \\ Silvia Graciele Hülse de Souza(1) and Deoclécio Domingos Garbuglio(1)
}

\begin{abstract}
(1)Universidade Estadual de Londrina (UEL), Dep. de Agronomia, Caixa Postal 6001, CEP 86051-990 Londrina, PR, Brazil. E-mail: danibruel@bol.com.br, pipolo@uel.br, cassio@uel.br, silviahulse@yahoo.com.br, deocleciodg@yahoo.com.br (2)Instituto Agronômico do Paraná, Dep. de Agronomia, Caixa Postal 481, CEP 86001-970 Londrina, PR, Brazil. E-mail: milhoger@iapar.br, nsfjr@iapar.br (3)UEL, Dep. de Biologia. E-mail: ruas@sercomtel.com.br
\end{abstract}

\begin{abstract}
The objective of this work was to evaluate the genetic diversity of 16 maize inbred lines, and to determine the correlation between genetic distance and hybrid performance, using random amplified polymorphic DNA (RAPD) molecular markers. Twenty-two different random primers were used, which resulted in the amplification of 265 fragments, 237 (84.44\%) of them being polymorphic. A genetic similarity matrix was created from the RAPD data, using Jaccard coefficient, and a dendrogram was constructed. Hybrid analyses were carried out using random block design and Griffing method VI for diallel crossings. The genetic associations showed five distinct heterotic groups. Correlations between genetic divergences detected by RAPD, as well as the means observed in the diallel crossings were positive and significant for plant height, ear height, prolificacy, and grain weight. The correlation of genetic divergences, detected by RAPD, and the specific combining ability between heterotic group associations, showed significance in all characteristics under study, except prolificacy. A direct relationship between genetic divergence and productivity was found in $79.2 \%$ of the 120 hybrids confirming the hypothesis that genetic divergence is directly related to the performance of hybrids and is efficient in predicting it.
\end{abstract}

Index terms: Zea mays, diallel, heterotic patterns, molecular markers.

\section{Distância genética estimada por marcadores RAPD e sua relação com o desempenho de híbridos em milho}

\begin{abstract}
Resumo - Este trabalho teve por objetivo utilizar marcadores moleculares de DNA (RAPD), para analisar a diversidade genética entre 16 linhagens elite de milho e estimar a correlação entre a distância e o desempenho de híbridos. Vinte e dois primers aleatórios resultaram na amplificação de 265 fragmentos, dos quais 237 (84,44\%) foram polimórficos. A partir dos marcadores RAPD, uma matriz de similaridade genética foi gerada, tendo-se usado o coeficiente de Jaccard, e um dendrograma foi construído. Para a avaliação dos híbridos resultantes dos dialelos, utilizaram-se blocos ao acaso e o método IV de Griffing. As associações genéticas obtidas mostraram cinco padrões heteróticos distintos. As correlações entre as divergências genéticas, detectadas por RAPD, e as médias observadas nos cruzamentos dialélicos foram positivas e significativas para as características altura de planta, altura de espiga, prolificidade e peso de grãos. As correlações das divergências genéticas, detectadas por RAPD, e a capacidade específica de combinação entre as associações de grupos heteróticos, mostraram significância em todas as características em estudo, exceto prolificidade. Dos 120 híbridos, 79,2\% apresentaram relação direta entre divergência genética e a produtividade, o que confirma a hipótese de que a divergência genética das linhagens está diretamente relacionada ao desempenho dos híbridos e é eficiente em predizê-lo.
\end{abstract}

Termos para indexação: Zea mays, dialelo, padrões heteróticos, marcadores moleculares.

\section{Introduction}

The maize hybrid development within a breeding program consists in obtaining lines and evaluating their combining ability. One of the most important decision that breeders have to make refers to the selection of populations for a breeding program. This decision must be as correct as possible, since a bad choice will imply on a waste of breeding time and resources.

Genetic diversity evaluation is frequently used by maize breeders as an alternative method for germplasm selection. The aim of this method is to select more promising materials and to decrease expenditures and 
time required to implement several hybrid combinations, which are sometimes unnecessary. Efforts are therefore focused on more promising combinations, that is, those between more divergent materials.

Although genetic diversity is a required condition for heterosis existence, it is not sufficient for heterosis to manifest itself, since it depends on the magnitude of the differences in allelic frequencies over the dominance effect, for all involved loci (Cress, 1966).

Genetic diversity can be obtained by means of physiological, morphological, agronomic, and molecular differences that exist between materials, and diversity can also be obtained by means of heterosis or through material specific combining ability (SCA), manifested in a series of crosses between varieties and hybrids (Melo et al., 2001).

According to Fuzatto et al. (2002), heterosis or the specific combining ability of two populations to cross depends on the existence of dominance in controlling the character, and on diversity between them, so that when parents are selected for those populations, preference should be given to parents that are divergent and already adapted. According to those authors, one of the alternatives, when choosing populations with higher heterosis, is to estimate diversity between them, and one of the methods used is diallelic cross.

The development of molecular biology techniques allowed genetic diversity to be evaluated by means of molecular markers, which present some advantages over other methods, because, in addition to identifying great polymorphism, they do not show interaction with different environments, and can also be evaluated at any developmental stage (Williams et al., 1990).

RAPD consists in the random amplification of DNA fragments with a single primer with an arbitrary sequence, resulting in the final synthesis of several DNA fragments with different sizes. From this set of fragments it is possible to determine polymorphism in the DNA sequence, which can be used as a genetic marker (Williams et al., 1990). In maize, this technique has been widely used in diversity studies because, in addition to its low cost, it allows polymorphism to be detected in a simple and fast manner (Liu et al., 1998; Wu, 2000).

Lanza et al. (1997) verified, from their research results, that RAPD can be used as an alternative to determine genetic diversity between maize lines, separating them into different heterotic groups, and to aid in selecting superior crosses, thus reducing the number of crosses required in field evaluations.
Ferreira et al. (1995) stated that heterosis and the combining ability of parents depend directly on the genetic diversity between them, and that the chance of finding promising combinations is better when more divergent materials are used. Therefore, when techniques of genetic diversity evaluation are used for accomplishment of diallelic cross, it is observed a reduction in the number of combinations, because crosses between progenitors with low genetic divergence result in not very productive hybrids.

The objective of this work was to analyze genetic diversity among 16 elite maize lines by means of RAPD markers, and to estimate the correlation between genetic distance and the performance of hybrids.

\section{Material and Methods}

Sixteen elite maize lines, from the genetic breeding program of Instituto Agronômico do Paraná (IAPAR), were used, belonging to five heterotic groups (Table 1): group A: L69 - line obtained by self-fertilization from the IPTT36 population introduced by CIMMYT (Centro Internacional de Mejoramiento de Maíz y Trigo, Mexico); Group B: L72 - line obtained by self-fertilization from a commercial triple hybrid; Group C: L89, L90, L91, L92, L93, and L94 - lines obtained by self-fertilization from a commercial single hybrid; Group D: L95, L96, L97, L98, L99, L100, and L101 - lines obtained by self-fertilization from an experimental single hybrid from IAPAR; and Group E: L102 - line obtained by self-fertilization within theAmarillo Cristalino variety from CIMMYT.

The 16 inbred lines were intercrossed according to a balanced diallelic scheme, without reciprocal ones, during the 2000/2001 cropping season, in Ponta Grossa, PR, Brazil, and produced 120 hybrids. The treatments consisted of the 120 hybrid combinations and two checks (C909 - Cargill single hybrid and P30F33 - Pioneer single hybrid). Experimental design was organized as randomized blocks with two replications. The experimental plots consisted of three 5-meter-long rows spaced at $0.9 \mathrm{~m}$. Five morphological characters were evaluated: female flowering (FF) - period (days) elapsed from emergence to silk emission; plant height $(\mathrm{PH})-$ measure $(\mathrm{cm})$ from the soil surface to the flag leaf curvature; ear height $(\mathrm{EH})$ - measure $(\mathrm{cm})$ from the soil surface to the insertion point of the highest ear; prolificacy (PROL) - determined by the ratio between numbers of ears/final stand; grain yield (GY) - adjusted to $\mathrm{kg} \mathrm{ha}^{-1}$, with a moisture degree corrected to $14.5 \%$, based on the grain yield obtained from all ears harvested in the plot. The moisture 
degree was determined as a percentage, immediately after weighting the grain.

Based on the analysis of hybrids, by means of analysis of variance, the treatment sums of squares were partitioned into general and specific combining abilities. The diallelic analysis was carried out using the method IV proposed by Griffing (1956), where only the hybrid $F_{1}$ is used: $Y_{i j}=m+g_{i}+g_{j}+s_{i j}+\varepsilon_{i j}$, in which $Y_{i j}$ is the medium value of the hybrid ij $(\mathrm{i}, \mathrm{j}=1,2, \ldots \mathrm{p}, \mathrm{I}<\mathrm{j})$; $\mathrm{m}$ is the general average; $g_{i}, g_{j}$ are the effects of the general combining abitility of the $\mathrm{i}$-th and $\mathrm{j}$-th progenitor, respectively; $\mathrm{s}_{\mathrm{ij}}$ is the effect of the specific combining ability for the crossings between the progenitors of $i$ and $\mathrm{j}$; and $\varepsilon_{\mathrm{ij}}$ is the medium error experimental.

In order to extract the DNA, seeds of the 16 lines were placed to germinate in towel paper. After 14 days, each line was represented by a bulk consisting of young leaves from three individuals. The leaves were macerated after being frozen in liquid nitrogen. The DNA extraction method used was based on the protocol described by Ferreira \& Grattapaglia (1998). DNA quantification was performed in a fluorometer and the samples were diluted to a final concentration of $10 \mathrm{ng} \mu \mathrm{L}^{-1}$ for amplification.

The amplification reactions were conducted in a final volume of $15 \mu \mathrm{L}$, containing: $1 \mathrm{X}$ buffer $(75 \mathrm{mM}$ Tris- $\mathrm{HCl}$ $\mathrm{pH} 9,50 \mathrm{mM} \mathrm{KCl}$, and $\left.2 \mathrm{mM}\left(\mathrm{NH}_{4}\right)_{2} \mathrm{SO}_{4}\right) ; 0.1 \mathrm{mM}$ of each dNTP; $0.5 \mathrm{mM}$ of primer; 0.7 unit of Taq DNA polymerase (Biotools); and 20 ng of DNA; and ultra-pure water to complete the volume. The amplifications were performed in a model PT-100 thermocycler (MJ Research, Massachusetts,
USA) programmed to an initial stage of $3 \mathrm{~min}$ at $94^{\circ} \mathrm{C}$, $471 \mathrm{~min}$ cycles at $94^{\circ} \mathrm{C}, 1.45 \mathrm{~min}$ at $38^{\circ} \mathrm{C}, 2 \mathrm{~min}$ at $72^{\circ} \mathrm{C}$, and a final stage of $6 \mathrm{~min}$ at $72^{\circ} \mathrm{C}$. After amplification, the total volume plus glycerol, was loaded on $1.2 \%$ agarose gel, containing ethidium bromide $\left(0.5 \mu \mathrm{g} \mathrm{mL}^{-1}\right)$. The amplified fragments were separated by electrophoresis in TAE buffer $(0.04 \mathrm{M}$ Tris-acetate and $0.01 \mathrm{M}$ EDTA $\mathrm{pH}$ 7.5), at $100 \mathrm{~V}$ for three hours. The fragments were visualized in ultraviolet light and the gel images were transferred to a microcomputer for analyses.

Twenty-two pre-selected decanucleotide primers (Operon Technologies, California, USA) were used in the RAPD reactions.

During gel evaluation, a similarity matrix was constructed where each band was treated as a single character, and its presence in an individual was designated as 1 and its absence in another individual was designated by 0 . This matrix was used to produce genetic distances between pairs of inbred lines; these distances were estimated between all possible pairs. The NTSYS-pc software program version 2.1 (Rohlf, 2000), was used to evaluate the genetic associations between samples. Pairwise comparisons were made between lines based on Jaccard similarity coefficient (Jaccard, 1901). The genetic similarity estimate (GS) between each pair of lines was calculated using the expression $\mathrm{GS}=\mathrm{a} /(\mathrm{n}-\mathrm{d})$, in which a is the number of positive coincidences; $\mathrm{n}$ is the total number of fragments; and $d$ is the number of negative coincidences. The genetic distances (GD) between pairs of lines were estimated by GD $=1$ - GS.

Table 1. Characterization of lines employed with regard to grain type, endosperm color, cycle, and heterotic groups.

\begin{tabular}{|c|c|c|c|c|c|}
\hline Number & Line & Grain type & Endosperm color & Cycle $^{(1)}$ & Heterotic group $^{(2)}$ \\
\hline 1 & L 69 & Semiflint & Orange & Early & $\mathrm{A}$ \\
\hline 2 & L 72 & Semiflint & Yellow & Early & B \\
\hline 3 & L 89 & Flint & Orange & Early & $\mathrm{C}$ \\
\hline 4 & L 90 & Semiflint & Orange & Super early & $\mathrm{C}$ \\
\hline 5 & L 91 & Semiflint & Yellow & Super early & $\mathrm{C}$ \\
\hline 6 & L 92 & Semident & Yellow/orange & Super early & $\mathrm{C}$ \\
\hline 7 & L 93 & Flint & Orange & Super early & $\mathrm{C}$ \\
\hline 8 & L94 & Flint & Orange & Super early & $\mathrm{C}$ \\
\hline 9 & L 95 & Semident & Yellow & Super early & $\mathrm{D}$ \\
\hline 10 & L 96 & Dent & Yellow & Super early & $\mathrm{D}$ \\
\hline 11 & L 97 & Semiflint & Yellow & Super early & $\mathrm{D}$ \\
\hline 12 & L 98 & Dent & Yellow & Super early & $\mathrm{D}$ \\
\hline 13 & L 99 & Dent & Yellow & Super early & $\mathrm{D}$ \\
\hline 14 & L 100 & Semi-flint & Yellow/orange & Super early & $\mathrm{D}$ \\
\hline 15 & L 101 & Dent & Yellow & Super early & $\mathrm{D}$ \\
\hline 16 & L 102 & Flint & Yellow/orange & Early & $\mathrm{E}$ \\
\hline
\end{tabular}

${ }^{(1)}$ Temperature requirements for cultivars: 780-830 growing degree days (GDD) - super early; 831-890 GDD - early. (2)Heterotic groups established with reference to source of the material and clustered according to Iapar. 
The simplified representation of distances was done using a dendrogram, obtained by the UPGMA clustering method, and through the scattering of maize lines in a bidimensional graph using the first two principal coordinates. The bootstrap procedure was applied to calculate variance of the genetic similarities obtained from the markers and, thus, to verify the consistency of the obtained dendrogram. The variance coefficient was obtained from 1,000 bootstrap random draws using the DBOOT program (Coelho, 2001).

The relation between Jaccard genetic distances and the means observed in diallelic crosses of heterotic group combinations were evaluated by Pearson correlations, using the Genes software (Cruz, 2001). Estimates were obtained for genetic diversity correlations between all characteristics under study (FF, PH, EH, PROL and GY) and the observed means, as well as for the correlation between genetic distance and the specific combining abilities of all heterotic groups combinations.

\section{Results and Discussion}

Twenty-two primers were used, producing a total of 265 amplified fragment-bands, with an average of 12.05 bands per primer. Of these, 237 were polymorphic (10.77 bands per primer), and 28 were monomorphic (1.27 bands per primer). The number of polymorphic bands varied from 3 for the OPAR-11 primer up to 18 for the OPAR-05 primer (Table 2).

Table 2. Primers used and their respective base sequences, number of amplified bands and number of polymorphic bands for the 16 maize lines analyzed.

\begin{tabular}{llcc}
\hline Primer & Sequence & $\begin{array}{c}\text { No. of } \\
\text { bands }\end{array}$ & $\begin{array}{c}\text { No. of polymorphic } \\
\text { bands }\end{array}$ \\
\hline OPAD-06 & AAGTGCACGG & 15 & 15 \\
OPAK-15 & ACCTGCCGTT & 13 & 11 \\
OPAM-01 & TCACGTACGG & 17 & 17 \\
OPAR-05 & CATACCTGCC & 18 & 18 \\
OPAR-10 & TGGGGCTGTC & 14 & 11 \\
OPAR-11 & GGGAAGACGG & 5 & 3 \\
OPAR-15 & ACACTCTGCC & 5 & 4 \\
OPAR-16 & CCTTGCGCCT & 6 & 5 \\
OPAT-08 & TCCTCGTGGG & 16 & 14 \\
OPAU-12 & CCACTCGTCT & 15 & 14 \\
OPAV-13 & CTGACTTCCC & 13 & 12 \\
OPAV-19 & CTCGATCACC & 13 & 12 \\
OPAW-10 & GTTGTTTGCC & 14 & 12 \\
OPAW-11 & CTGCCACGAG & 19 & 17 \\
OPAW -19 & GGACACAGAG & 12 & 10 \\
OPAX-10 & CCAGGCTGAC & 9 & 8 \\
OPP-05 & CCCCGGTAAC & 11 & 10 \\
OPP-14 & CCAGCCGAAC & 8 & 7 \\
OPW-03 & GTCCGGAGTG & 12 & 12 \\
OPW-08 & GACTGCCTCT & 7 & 5 \\
OPW-09 & GTGACCGAGT & 9 & 7 \\
OPW-13 & CACAGCGACA & 14 & 13 \\
\hline & & &
\end{tabular}

The level of polymorphism $(84.44 \%)$ obtained was higher than in some maize studies, such as Melo et al. (2001), who obtained $61.46 \%$ of polymorphic bands working with hybrids, and Lanza et al. (1997), who obtained $80.6 \%$ of polymorphism studying genetic divergence between inbred lines using RAPD markers. The level of polymorphism to be obtained depends on the degree of divergence between the genotypes under study. The primers used in this study were rigorously pre-selected, taking into account the number and quality of the amplification products, and this may have contributed to increase the polymorphism.

Dendrogram stability is an important aspect to be considered in genetic variability studies (Carvalho et al., 2004). Analysis of genetic diversity involving maize inbred lines showed that 150 polymorphic bands were sufficient to stabilize the dendrogram (Lanza et al., 1997). According to Figure 1, and based on the bootstrap method, it can be observed that starting from approximately 180 bands, the coefficient of variation for the genetic distances $(11.3 \%)$ between genotypes becomes stabilized, which indicates that 180 randomlysampled bands would produce the same cluster obtained with the 265 bands used in this study. Pejic et al. (1998) used Dice coefficient and verified that when RAPD markers are used starting from 100 bands, practically no change occurs in the coefficient of variation for the genetic distances between genotypes. However, the number of bands giving a particular variation coefficient depends on the nature of the genotypes and of the coefficient used (Thormann et al., 1994).

Based on the 237 polymorphic bands obtained, a genetic distance matrix was constructed using the complement of Jaccard's similarity coefficient, listing all maize line pairs. Genetic distances (GD) among pairs of

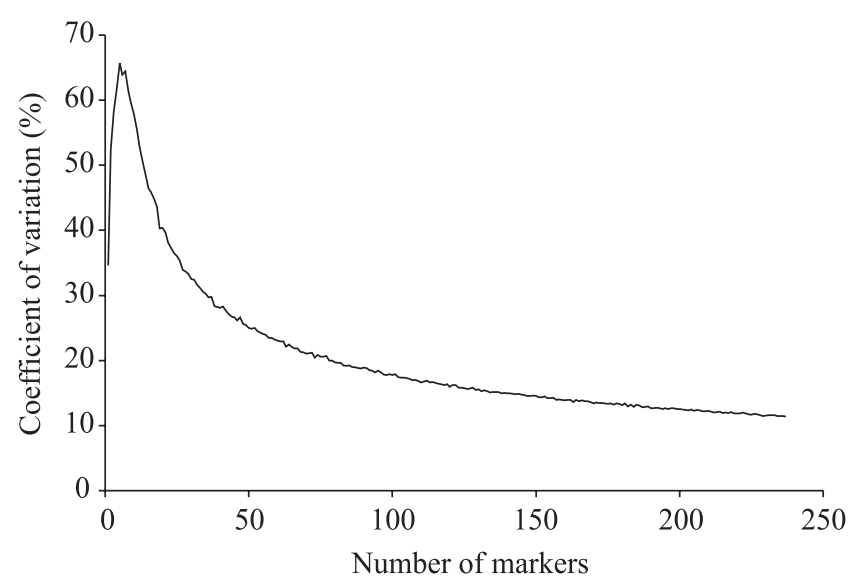

Figure 1. Coefficient of variation for the number of markers, estimated from 1,000 bootstrap random draws. The coefficient of variation for the 237 bands was $11.3 \%$. 
Table 3. Genetic distances between 16 maize lines analyzed in a pairwise fashion.

\begin{tabular}{|c|c|c|c|c|c|c|c|c|c|c|c|c|c|c|c|c|}
\hline & L 69 & L 72 & L 89 & L 90 & L 91 & L 92 & L 93 & L 94 & L 95 & L 96 & L 97 & L 98 & L 99 & L 100 & L 101 & L 102 \\
\hline L 69 & 0 & & & & & & & & & & & & & & & \\
\hline L 72 & 0.52 & 0 & & & & & & & & & & & & & & \\
\hline L 89 & 0.49 & 0.53 & 0 & & & & & & & & & & & & & \\
\hline L 90 & 0.55 & 0.54 & 0.29 & 0 & & & & & & & & & & & & \\
\hline L 91 & 0.53 & 0.57 & 0.43 & 0.31 & 0 & & & & & & & & & & & \\
\hline L 92 & 0.50 & 0.49 & 0.42 & 0.46 & 0.44 & 0 & & & & & & & & & & \\
\hline L 93 & 0.51 & 0.53 & 0.41 & 0.36 & 0.38 & 0.42 & 0 & & & & & & & & & \\
\hline L 94 & 0.54 & 0.55 & 0.51 & 0.48 & 0.53 & 0.52 & 0.44 & 0 & & & & & & & & \\
\hline L 95 & 0.57 & 0.52 & 0.53 & 0.53 & 0.55 & 0.49 & 0.54 & 0.55 & 0 & & & & & & & \\
\hline L 96 & 0.58 & 0.51 & 0.55 & 0.55 & 0.57 & 0.52 & 0.53 & 0.55 & 0.40 & 0 & & & & & & \\
\hline L 97 & 0.62 & 0.59 & 0.59 & 0.59 & 0.62 & 0.54 & 0.57 & 0.55 & 0.40 & 0.47 & 0 & & & & & \\
\hline L 98 & 0.58 & 0.51 & 0.52 & 0.57 & 0.57 & 0.51 & 0.53 & 0.57 & 0.39 & 0.37 & 0.45 & 0 & & & & \\
\hline L 99 & 0.55 & 0.52 & 0.53 & 0.55 & 0.58 & 0.54 & 0.50 & 0.51 & 0.33 & 0.36 & 0.45 & 0.32 & 0 & & & \\
\hline L 100 & 0.56 & 0.48 & 0.51 & 0.55 & 0.55 & 0.50 & 0.51 & 0.54 & 0.38 & 0.38 & 0.47 & 0.34 & 0.27 & 0 & & \\
\hline L 101 & 0.57 & 0.54 & 0.56 & 0.58 & 0.60 & 0.56 & 0.52 & 0.57 & 0.45 & 0.35 & 0.50 & 0.43 & 0.30 & 0.34 & 0 & \\
\hline L 102 & 0.60 & 0.61 & 0.56 & 0.59 & 0.62 & 0.62 & 0.58 & 0.60 & 0.63 & 0.55 & 0.64 & 0.56 & 0.54 & 0.57 & 0.52 & 0 \\
\hline
\end{tabular}

inbred lines ranged from 0.27 to 0.64 , for the 120 hybrids, with an average of 0.51 (Table 3 ). The smallest genetic distance obtained was observed between lines L99 and L100, while the greatest distance was between lines L97 and L102. These results confirm that the analysis of genetic divergence by RAPD markers is a valid procedure, since the smallest divergence was observed for a cross between lines belonging to the same heterotic group, and the greatest divergence was observed for a cross between lines belonging to different heterotic groups. Souza Sobrinho et al. (2001) obtained a mean genetic divergence of 0.65 between seven commercial maize hybrids.

Figure 2 presents the dendrogram for inbred lines, according to the UPGMA clustering method. The 16 lines were separated into five distinct groups, which were in agreement with the heterotic patterns described by Iapar, which were pre-established based on their genealogy.

Lanza et al. (1997) reported that RAPD markers are useful to establish consistent heterotic groups between maize lines. This statement agrees with the results obtained in this study, where the same markers were efficient to separate the 16 lines into 5 heterotic groups, confirming the previous separation of those lines according to their genealogy.

Considering the genetic distances detected by the RAPD markers, the first heterotic group (A) is only comprised by line L69; the second group (B) is comprised by line L72; the third heterotic group (C) comprises lines L89, L90, L91, L92, L93, and L94; the fourth group (D) is formed by lines L95, L96, L97, L98, L99, L100, and L101; and the fifth and last group (E) is comprised by line L102.

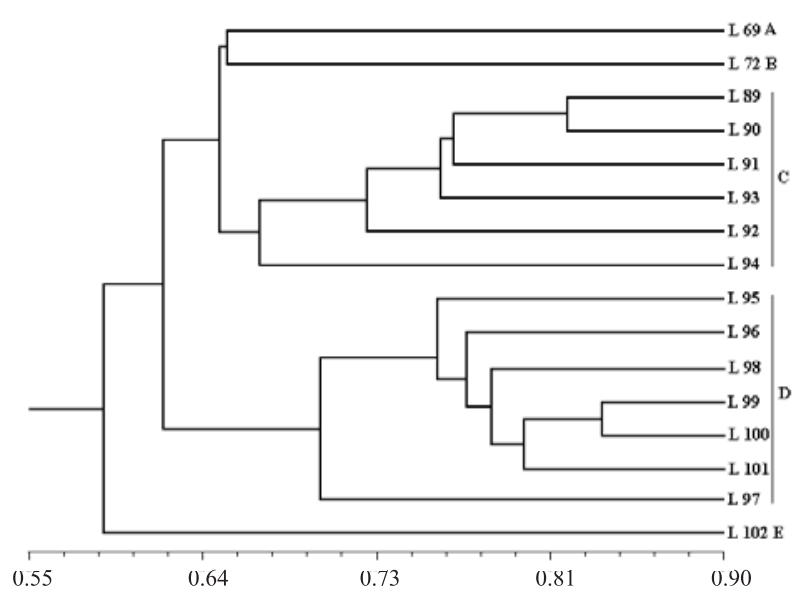

Figure 2. UPGMA clustering for the 16 maize inbred lines based on Jaccard genetic similarities from RAPD data.

The mean genetic distance obtained among all combinations of these five heterotic groups was 0.51 (Table 4); the highest mean was 0.61 between $\mathrm{B} \times \mathrm{E}$ combination, and the lowest means were obtained with $\mathrm{C} \times \mathrm{C}$ and $\mathrm{D} \times \mathrm{D}$ combinations, with 0.43 and 0.39 , respectively. Such results were expected, since the combinations between similar heterotic groups could only present genetic divergence means lower than the combinations between distinct groups. The associations $\mathrm{A} \times \mathrm{A}, \mathrm{B} \times \mathrm{B}$, and $\mathrm{E} \times \mathrm{E}$ are not shown in the table, since no hybrids resulted from them, due to the fact that groups $\mathrm{A}, \mathrm{B}$, and $\mathrm{E}$ consisted of a single line.

The highest mean observed for the grain weight trait was for $\mathrm{A} \times \mathrm{C}$ combination, with $10,619 \mathrm{~kg} \mathrm{ha}^{-1}$ (Table 5); this association of groups showed a genetic distance of 0.52 . 
The lowest means observed for this trait corresponded to $\mathrm{C} \times \mathrm{C}$ and $\mathrm{D} \times \mathrm{D}$ combinations, with 6,390 and $4,490 \mathrm{~kg} \mathrm{ha}^{-1}$, and genetic distance of 0.43 and 0.39 , respectively. These results are useful to confirm Falconer's statement (1981) according to whom the higher is the genetic distance between crossed materials, the higher is the heterosis, and consequently, the higher is the productivity.

Correlations between genetic distances detected by RAPD and the means observed in diallelic crosses were positive and significant for plant height $(\mathrm{r}=0.445)$, ear height $(r=0.335)$, prolificacy $(r=0.342)$, and grain weight traits $(r=0.680)$ (Table 6). Lanza et al. (1997), using tropical maize lines, also found direct and positive

Table 4. Number of hybrids (N), mean, minimum, maximum, and standard deviation (SD) for genetic distances estimated by RAPD between combinations of heterotic groups, established by polymorphism analysis of 237 amplified fragments in a RAPD marker analysis for 16 maize inbred lines.

\begin{tabular}{lrcccc}
\hline Group combinations & $\mathrm{N}$ & Mean & Min & Max & $\mathrm{SD}$ \\
\hline $\mathrm{A} \times \mathrm{B}$ & 1 & 0.52 & 0.52 & 0.52 & - \\
$\mathrm{A} \times \mathrm{C}$ & 6 & 0.52 & 0.49 & 0.55 & 0.023 \\
$\mathrm{~A} \times \mathrm{D}$ & 7 & 0.58 & 0.55 & 0.62 & 0.022 \\
$\mathrm{~A} \times \mathrm{E}$ & 1 & 0.60 & 0.60 & 0.60 & - \\
$\mathrm{B} \times \mathrm{C}$ & 6 & 0.53 & 0.49 & 0.57 & 0.027 \\
$\mathrm{~B} \times \mathrm{D}$ & 7 & 0.52 & 0.48 & 0.59 & 0.034 \\
$\mathrm{~B} \times \mathrm{E}$ & 1 & 0.61 & 0.61 & 0.61 & - \\
$\mathrm{C} \times \mathrm{D}$ & 42 & 0.55 & 0.49 & 0.62 & 0.029 \\
$\mathrm{C} \times \mathrm{E}$ & 6 & 0.59 & 0.56 & 0.62 & 0.023 \\
$\mathrm{D} \times \mathrm{E}$ & 7 & 0.57 & 0.52 & 0.64 & 0.045 \\
$\mathrm{C} \times \mathrm{C}$ & 15 & 0.43 & 0.29 & 0.53 & 0.071 \\
$\mathrm{D} \times \mathrm{D}$ & 21 & 0.39 & 0.27 & 0.50 & 0.061 \\
\hline Total & 120 & 0.51 & 0.27 & 0.64 & 0.083 \\
\hline & & & & &
\end{tabular}

correlations between RAPD-based genetic distances and grain productivity in single hybrids of maize.

The correlation between genetic distance detected by RAPD markers and the specific combining ability (SCA) between heterotic group combinations (Table 7) were significant for all traits, except for prolificacy. A positive and significant correlation of 0.562 was obtained for the grain weight trait; the highest correlation for this trait occurred in $\mathrm{A} \times \mathrm{D}$ combinations $(\mathrm{r}=0.669)$, while the lowest occurred in the $\mathrm{C} \times \mathrm{E}$ combinations, with $\mathrm{r}=-0.327$. It is worth pointing out that the comparisons between estimates are based in a lack of balance between groups, that is, the groups do not have the same number of crosses; in view of this, it is necessary to evaluate the magnitude of values. Ajmone-Marsan et al. (1998) compared the use of RFLP and AFLP markers, in order to determine genetic divergence between 13 maize lines, as well as to verify the relation between genetic distance and the performance of hybrids in diallelic crosses. The results showed positive but small correlations between genetic distance and the performance of single hybrids for the grain yield character. Authors also concluded that genetic distance correlations using AFLP data, containing specific combining ability effects for grain yield, could be useful in hybrid prediction, which reinforces the use of genetic divergence analysis as detected by RAPD markers to predict maize single hybrids.

The 120 hybrids were projected onto a plane, where the $\mathrm{X}$ coordinate consisted of genetic distance and the $\mathrm{Y}$ coordinate consisted of the grain weight trait $\left(\mathrm{kg} \mathrm{ha}^{-1}\right)$ (Figure 3). This plane was divided into quadrants, taking

Table 5. Number of hybrids (N), genetic distance (GD) detected by RAPD markers, and means observed in diallelic crosses between 16 maize inbred lines, for the characters: days to female flowering (FF), plant height in $\mathrm{cm}(\mathrm{PH})$, ear height in $\mathrm{cm}(\mathrm{EH})$, prolificacy (PROL), and grain weight in $\mathrm{kg} \mathrm{ha}^{-1}(\mathrm{GW})$.

\begin{tabular}{|c|c|c|c|c|c|c|c|}
\hline Group combinations & $\mathrm{N}$ & GD & $\mathrm{FF}$ & PH & $\mathrm{EH}$ & PROL & GW \\
\hline $\mathrm{A} \times \mathrm{B}$ & 1 & 0.52 & 74.0 & 190.0 & 90.0 & 1.04 & 9,103 \\
\hline $\mathrm{A} \times \mathrm{C}$ & 6 & 0.52 & 73.0 & 211.7 & 101.7 & 1.00 & 10,619 \\
\hline$A \times D$ & 7 & 0.58 & 73.9 & 223.9 & 103.6 & 1.00 & 10,428 \\
\hline $\mathrm{A} \times \mathrm{E}$ & 1 & 0.60 & 81.5 & 240.0 & 125.0 & 1.03 & 9,691 \\
\hline $\mathrm{B} \times \mathrm{C}$ & 6 & 0.53 & 71.6 & 227.9 & 105.0 & 1.02 & 9,739 \\
\hline $\mathrm{B} \times \mathrm{D}$ & 7 & 0.52 & 72.7 & 231.4 & 100.7 & 1.00 & 9,905 \\
\hline $\mathrm{B} \times \mathrm{E}$ & 1 & 0.61 & 79.5 & 237.5 & 120.0 & 0.96 & 7,540 \\
\hline $\mathrm{C} \times \mathrm{D}$ & 42 & 0.55 & 68.7 & 197.1 & 85.6 & 1.00 & 8,298 \\
\hline $\mathrm{C} \times \mathrm{E}$ & 6 & 0.59 & 73.3 & 212.1 & 94.6 & 1.11 & 9,873 \\
\hline $\mathrm{D} \times \mathrm{E}$ & 7 & 0.57 & 76.8 & 215.0 & 96.1 & 1.02 & 9,572 \\
\hline $\mathrm{C} \times \mathrm{C}$ & 15 & 0.43 & 70.1 & 186.5 & 85.5 & 1.01 & 6,390 \\
\hline $\mathrm{D} \times \mathrm{D}$ & 21 & 0.39 & 72.2 & 183.9 & 78.7 & 0.90 & 4,990 \\
\hline Total & 120 & 0.51 & 73.6 & 213.1 & 99.0 & 1.01 & 8,052 \\
\hline
\end{tabular}


Table 6. Number of hybrids (N), genetic distance mean (GD) detected by RAPD, and their respective correlations with the means observed for the characters: days to female flowering (FF), plant height in $\mathrm{cm}(\mathrm{PH})$, ear height in $\mathrm{cm}(\mathrm{EH})$, prolificacy (PROL), and grain weight in $\mathrm{kg} \mathrm{ha}^{-1}(\mathrm{GW})$ between combinations of heterotic groups from 16 maize inbred lines.

\begin{tabular}{|c|c|c|c|c|c|c|c|}
\hline Group combinations & $\mathrm{N}$ & GD & $\begin{array}{c}\mathrm{FF} \\
\mathrm{r}\end{array}$ & $\begin{array}{c}\mathrm{PH} \\
\mathrm{r}\end{array}$ & $\begin{array}{c}\mathrm{EH} \\
\mathrm{r}\end{array}$ & $\begin{array}{c}\text { PROL } \\
\mathrm{r}\end{array}$ & $\begin{array}{c}\text { GW } \\
\mathrm{r}\end{array}$ \\
\hline$A \times B$ & 1 & 0.52 & - & - & - & - & - \\
\hline $\mathrm{A} \times \mathrm{C}$ & 6 & 0.52 & 0.421 & -0.767 & -0.644 & 0.622 & 0.621 \\
\hline $\mathrm{A} \times \mathrm{D}$ & 7 & 0.58 & -0.283 & -0.210 & -0.463 & -0.135 & -0.238 \\
\hline $\mathrm{A} \times \mathrm{E}$ & 1 & 0.60 & - & - & - & - & - \\
\hline $\mathrm{B} \times \mathrm{C}$ & 6 & 0.53 & 0.717 & $-0.912 *$ & -0.452 & 0.384 & 0.617 \\
\hline$B \times D$ & 7 & 0.52 & -0.556 & -0.441 & -0.436 & -0.303 & -0.399 \\
\hline $\mathrm{B} \times \mathrm{E}$ & 1 & 0.61 & - & - & - & - & - \\
\hline $\mathrm{C} \times \mathrm{D}$ & 42 & 0.55 & 0.056 & -0.185 & -0.116 & -0.094 & -0.121 \\
\hline $\mathrm{C} \times \mathrm{E}$ & 6 & 0.59 & -0.344 & 0.130 & 0.565 & -0.663 & -0.094 \\
\hline $\mathrm{D} \times \mathrm{E}$ & 7 & 0.57 & 0.134 & -0.698 & -0.371 & 0.374 & 0.137 \\
\hline $\mathrm{C} \times \mathrm{C}$ & 15 & 0.43 & -0.069 & 0.238 & 0.099 & 0.039 & 0.336 \\
\hline $\mathrm{D} \times \mathrm{D}$ & 21 & 0.39 & 0.016 & -0.393 & -0.287 & -0.054 & -0.099 \\
\hline Total & 120 & 0.51 & 0.062 & $0.445^{*}$ & $0.335^{*}$ & $0.342 *$ & $0.680^{*}$ \\
\hline
\end{tabular}

*Significant.

Table 7. Number of hybrids (N), genetic distance mean (GD) detected by RAPD, and their respective correlations with the specific combining ability (SCA) for the characters: days to female flowering (FF), plant height in $\mathrm{cm}(\mathrm{PH})$, ear height in $\mathrm{cm}(\mathrm{EH})$, prolificacy (PROL), and grain weight in $\mathrm{kg} \mathrm{ha}^{-1}(\mathrm{GW})$ between combinations of heterotic groups from 16 maize inbred lines.

\begin{tabular}{lccccccc}
\hline Group combinations & $\mathrm{N}$ & $\mathrm{GD}$ & $\begin{array}{c}\mathrm{FF} \\
\mathrm{r}\end{array}$ & $\begin{array}{c}\mathrm{PH} \\
\mathrm{r}\end{array}$ & $\begin{array}{c}\mathrm{EH} \\
\mathrm{r}\end{array}$ & $\begin{array}{c}\text { PROL } \\
\mathrm{r}\end{array}$ & $\begin{array}{c}\text { GW } \\
\mathrm{r}\end{array}$ \\
\hline $\mathrm{A} \times \mathrm{B}$ & 1 & 0.52 & - & - & - & - & - \\
$\mathrm{A} \times \mathrm{C}$ & 6 & 0.52 & 0.616 & -0.529 & -0.45 & 0.664 & 0.664 \\
$\mathrm{~A} \times \mathrm{D}$ & 7 & 0.58 & 0.612 & 0.003 & -0.361 & 0.006 & 0.669 \\
$\mathrm{~A} \times \mathrm{E}$ & 1 & 0.60 & - & - & - & - & - \\
$\mathrm{B} \times \mathrm{C}$ & 6 & 0.53 & 0.332 & -0.070 & -0.281 & 0.212 & 0.647 \\
$\mathrm{~B} \times \mathrm{D}$ & 7 & 0.52 & -0.360 & -0.115 & -0.280 & -0.175 & 0.218 \\
$\mathrm{~B} \times \mathrm{E}$ & 1 & 0.61 & - & - & - & - & - \\
$\mathrm{C} \times \mathrm{D}$ & 42 & 0.55 & -0.021 & 0.092 & 0.136 & -0.165 & 0.020 \\
$\mathrm{C} \times \mathrm{E}$ & 6 & 0.59 & -0.025 & -0.041 & 0.806 & -0.706 & -0.327 \\
$\mathrm{D} \times \mathrm{E}$ & 7 & 0.57 & 0.127 & -0.535 & -0.353 & 0.464 & 0.330 \\
$\mathrm{C} \times \mathrm{C}$ & 15 & 0.43 & -0.233 & 0.242 & 0.161 & 0.058 & 0.110 \\
$\mathrm{D} \times \mathrm{D}$ & 21 & 0.39 & -0.079 & -0.247 & 0.019 & -0.039 & 0.052 \\
\hline Total & 120 & 0.51 & $-0.339 *$ & $0.391^{*}$ & $0.184 *$ & 0.171 & $0.562 *$ \\
\hline Significant & & & & & & &
\end{tabular}

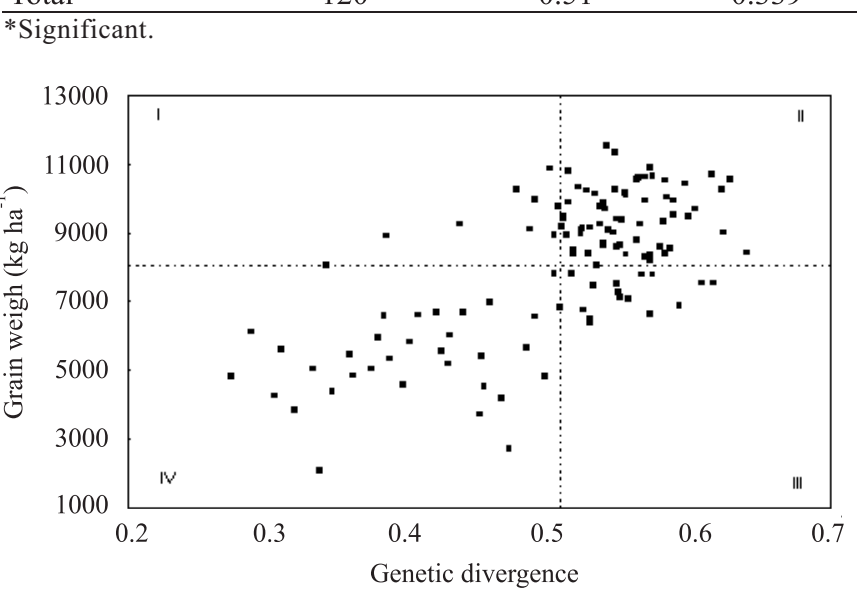

Figure 3. Association between genetic distance from 16 maize parental lines and grain weight $\left(\mathrm{kg} \mathrm{ha}^{-1}\right)$ from 120 hybrids. The quadrants were divided following the mean values of their corresponding axes. into account the average genetic distance $(0.51)$ and the mean observed for grain weight $\left(8,052 \mathrm{~kg} \mathrm{ha}^{-1}\right)$. Nine hybrids showing low genetic distance and high grain weight were allocated in the first quadrant (I); the second quadrant (II) contained 62 hybrids showing high distance and high grain weight; the third quadrant (III) contained 16 hybrids showing high distance and low grain weight; and the fourth quadrant (IV) received 33 of the 120 hybrids, showing low distance and low grain weight. Therefore, the hybrids allocated in quadrants II and IV (79.2\% of all hybrids) confirm the hypothesis that genetic distance is directly related to hybrid performance, and is efficient to predict them, when it comes to elite maize lines. 


\section{Conclusions}

1. The genetic distance revealed by RAPD markers can be used to establish consistent heterotic patterns between maize inbred lines.

2. There are direct, positive, and significant correlations between the genetic distances estimated by RAPD markers and the productivity of hybrids from the 16 elite maize lines under study.

3 . The genetic distances estimated by RAPD molecular markers can be used to predict crosses with greater performance for grain production, and to allocate genotypes into different heterotic patterns, noticeably reducing the number of crosses to be evaluated.

\section{Acknowledgements}

To Capes and $\mathrm{CNPq}$, for supporting this work.

\section{References}

AJMONE-MARSAN, P.; CASTIGLIONI, P.; FUSARI, F.; KUIPER, M.; MOTTO, M. Genetic diversity and its relationship to hybrid performance in maize as revealed by RFLP and AFLP markers. Theoretical and Applied Genetics, v.96, p.219-227, 1998.

CARVALHO, V.P.; RUAS, C.F.; FERREIRA, J.M.; MOREIRA, R.M.P.; RUAS, P.M. Genetic diversity among maize (Zea mays L.) landraces assessed by RAPD markers. Genetics and Molecular Biology, v.27, p.28-36, 2004.

COELHO, A.S.G. DBOOT: avaliação dos erros associados a estimativas de distâncias/similaridades genéticas através do procedimento de bootstrap com número variável de marcadores. Versão 1.1. Goiânia: Universidade Federal de Goiás, 2001.

CRESS, C.E. Heterosis of the hybrid related to gene frequency differences between two populations. Genetics, v.53, p.269-274, 1966.

CRUZ, C.D. Programa Genes: versão Windows. Viçosa: UFV, 2001. 648p.

FALCONER, D.S. Introduction to Quantitative Genetics. $2^{\text {nd }}$ ed. London: Longman, 1981. 340p.

FERREIRA, D.F.; OLIVEIRA, A.C.; SANTOS, M.X. dos; RAMALHO, M.A.P. Métodos de avaliação da divergência genética em milho e suas relações com os cruzamentos dialélicos. Pesquisa Agropecuária Brasileira, v.30, p.1189-1194, 1995.
FERREIRA, M.E.; GRATTAPAGLIA, D. Introdução ao uso de marcadores moleculares em análise genética. 3.ed. Brasília: Embrapa-Cenargen, 1998. 220p.

FUZATTO, S.R.; FERREIRA, D.F.; RAMALHO, M.A.P.; RIBEIRO, P.H.E. Divergência genética e sua relação com os cruzamentos dialélicos na cultura do milho. Ciência e Agrotecnologia, v.26, p.22-32, 2002.

GRIFFING, B. Concept of general and specific combining ability in relation to dialel crossing sistems. Australian Journal of Biological Sciences, v.9, p.463-493, 1956.

JACCARD, P. Étude comparative de la distribution florale dans une portion des Alpes et des Jura. Bulletin de la Societé Vaudoise des Sciences Naturelles, v.37, p.547-579, 1901.

LANZA, L.L.B.; SOUZA JÚNIOR, C.L.; OTTOBONI, L.M.N.; VIEIRA, M.L.C.; SOUZA, A.P. Genetic distance of inbread lines and prediction of maize single-cross performance using RAPD markers. Theoretical and Applied Genetics, v.94, p.1023-1030, 1997.

LIU, X.; PENG, Z.; FU, J.; HUANG, C.; LIU, X.Z.; PENG, Z.B.; FU, J.H.; HUANG, C.L. Maize inbred line grouping by using cluster analysis of RAPD molecular marker, phenotype and heterosis. Acta Agriculturae Boreali Sinica, v.13, p.36-41, 1998.

MELO, W.M.C.; PINHO, R.G.V.; SANTOS, J.B. dos; FERREIRA, D.F. Utilização de caracteres morfoagronômicos e marcadores moleculares para avaliação da divergência entre híbridos de milho. Revista Ceres, v.48, p.195-207, 2001.

PEJIC, I.; AJMONE-MARSAN, P.; MORGANTE, M.; KOZUMPLICK, V.; CASTIGLIONI, P.; TARAMINO, G.; MOTTO, M. Comparative analysis of genetic similarity among maize inbred lines detected by RFLPs, RAPDs, SSRs and AFLPs. Theoretical and Applied Genetics, v.97, p.1248-1255, 1998.

ROHLF, F.J. NTSYS-pc: numerical taxonomy and multivariate analysis system. Version 2.1. New York: Exeter, 2000. 38p.

SOUZA SOBRINHO, F.; RAMALHO, M.A.P.; SOUZA, J.C. Genetic diversity and inbreeding potential of maize commercial hybrids. Maydica, v.46, p.171-175, 2001.

THORMANN, C.E.; FERREIRA, M.E.; CAMARGO, L.E.A.; TIVANG, J.G.; OSBORN, T.C. Comparison of RFLP and RAPD markers for estimating genetic relationships within and among cruciferous species. Theoretical and Applied Genetics, v.88, p.973980, 1994.

WILLIAMS, J.G.K.; KUBELIK, A.R.; LIVAK, K.J.; RAFALSKI, J.A.; TINGEY, S.V. DNA polymorphisms amplified by arbitrary primers are useful as genetic markers. Nucleic Acids Research, v.18, p.6531-6535, 1990.

WU, M. Genetic diversity and its relationship to hybrid performance and heterosis in maize as revealed by AFLPs and RAPDs. Maize Genetics Cooperation Newsletter, v.74, p.62-63, 2000.

$\overline{\text { Received on November 22, } 2005 \text { and accepted on July 12, } 2006}$ 